\title{
3D NUMERICAL ANALYSIS OF HEAT EXCHANGE IN BUILDING STRUCTURES WITH CAVITIES
}

\author{
J. Grechenkovs, A. Jakovich, S. Gendelis \\ University of Latvia, Faculty of Physics and Mathematics, Laboratory for \\ Mathematical Modelling of Environmental and Technological Processes, \\ 8 Zellu Str., Riga, LV-1002, LATVIA \\ jurijs.grecenkovs@gmail.com
}

\begin{abstract}
In the paper, the heat transfer inside a building block with cavities is analyzed and a brief overview of the relevant physical problem is given. The equations governing the heat exchange processes are presented and a numerical model is derived with the help of ANSYS software. The role of radiation and convection inside the cavities is emphasized throughout the work. The results show that in such cavities the radiation mechanism of heat transfer is dominant. The authors also examine the dependence of the effective heat conductivity on the properties of clay material. Using the numerical model, attempts have been made to improve the heat resistance of a building block. Possibilities of practical application of numerical modelling in the heat insulation material engineering are discussed.
\end{abstract}

Key words: numerical modelling, effective heat conductivity, convection, radiation, heat conduction, building block.

\section{INTRODUCTION}

\subsection{Description of the problem}

Empirical observations show that a notable influence on the heat transfer through the walls of a building can be achieved by arranging the gas inclusions inside its blocks. This influence can be analyzed quantitatively using experimental methods, or by numerical modelling of the heat exchange processes inside the building structures. The efficiency of the second approach is partially determined by low costs for running the tests (since materials can be modelled even before they have been produced) and the ability to obtain the needed results immediately. Numerical modelling has been realized in two-dimensional approximation for a similar problem in the works of other authors (see, e.g. [1]).

In the present work, specific block geometry is chosen and a 3D model is developed, which allows for correct representation of the convection heat transfer. The aim of this work is to develop the methods which would allow describing the properties of heat transfer in a building block using numerical modelling.

Heat resistance $R\left(\mathrm{~m}^{2} \cdot \mathrm{K} \cdot \mathrm{W}^{-1}\right)$, heat transmittance $U\left(\mathrm{~W} \cdot \mathrm{m}^{-2} \cdot \mathrm{K}^{-1}\right)$, and effective heat conductivity $\lambda_{\text {eff }}\left(\mathrm{W} \cdot \mathrm{m}^{-1} \cdot \mathrm{K}^{-1}\right)$ are usually examined when comparing the heat transfer inside the building materials. These quantities are determined by the following formulae: 


$$
R=\frac{S \cdot \Delta T}{Q} ; \quad \frac{1}{U}=R+\frac{1}{h_{\text {out }}}+\frac{1}{h_{\text {in }}} ; \quad \lambda_{\text {eff }}=U \cdot l
$$

where $Q \quad$ is the heat flux (W);

$S \quad$ is the area $\left(\mathrm{m}^{2}\right)$ through which the heat transfer proceeds;

$\Delta T \quad$ is the difference of temperatures on the inner and outer surfaces of the wall (K);

$l \quad$ is the thickness of the wall (m);

$h_{\text {out }}$ and $h_{\text {in }}$ are heat exchange coefficients between the environment and outer or inner surfaces of the wall $\left(\mathrm{W} \cdot \mathrm{m}^{-2} \cdot \mathrm{K}^{-1}\right)$;

$\lambda_{\text {eff }}$ is a convenient choice for monitoring the inclusion effect of the cavities because this can be compared with the heat conductivity of the building block material (clay);

$U$ and $R \quad$ are specifications of the whole wall structures.

The reason for the absence of analytical formulae for calculating the parameters described above is their strong dependence on the geometrical distribution of locations and sizes of the cavities and a complicated heat transfer mechanism inside the inclusions. To better grasp these issues, the conductive, convective and radiation heat transfer mechanisms are to be analyzed with a threedimensional modelling involved.

\subsection{Mathematical description of the processes}

The heat transfer in solid materials is determined by Fourier's law:

$$
\vec{q}=-\lambda \nabla T,
$$

where $\vec{q}$ is the heat flux density;

$\lambda$ is the heat conductivity;

$T$ is temperature.

The thermodynamic balance for fluids is given by a more complex equation:

$$
\rho c_{p}\left(\frac{\partial T}{\partial t}+(\vec{v} \nabla) T\right)=\lambda \nabla^{2} T,
$$

where $\rho$ - the density,

$c_{p}$ - heat capacity and

$\vec{v}$ - velocity of the medium.

Term $(\vec{v} \nabla) T$ stands for convection and therefore can be neglected for solids.

The motion of fluid is given by Navier-Stoke's equation in the Boussinesque approximation:

$$
\left\{\begin{array}{c}
\frac{\partial \vec{v}}{\partial t}+(\vec{v} \nabla) \vec{v}=-\frac{1}{\rho} \nabla p+v\left(\nabla^{2} \vec{v}\right)+\vec{f}-\vec{g} \\
\nabla \vec{v}=0
\end{array},\right.
$$

with the buoyancy force $\vec{f}$ to be derived from the equation:

$$
\vec{f}=\beta\left(T-T_{0}\right) \vec{g} .
$$


In these equations,

$\vec{g}$ - the gravitational acceleration,

$p$ - the pressure,

$v$ - kinematic viscosity,

$\beta$ - thermal expansion coefficient,

$T_{0}$ - reference temperature.

Since it is necessary to seek out only the steady state solutions, the terms containing time derivatives could be neglected.

The discrete model can be employed for the radiation heat transfer in a transparent medium, which is determined by the following equation [2]:

$$
I(s)=\frac{\sigma_{S B} T^{4}}{\pi}\left(1-e^{-\alpha \cdot s}\right)+I_{0} e^{-\alpha \cdot s},
$$

where $I$ is the radiation intensity in a definite direction,

$\alpha$ is the absorption coefficient,

$s \quad$ is the distance from the radiation source,

$\sigma_{S B}$ is Stefan-Boltzmann's constant.

All results in this work have been obtained with the ANSYS CFX modelling software [3].

\section{MODELLING AND MESHING}

\subsection{Model}

A building block from the JSC "LODE" product range [4] was chosen as an object for developing the methods of heat transfer analysis. This block had internal cavities of different sizes (Fig. 1a). The concavities on the side surfaces of the block were filled with concrete gluing. The relevant geometrical model of the block is shown in Fig $1 b$.

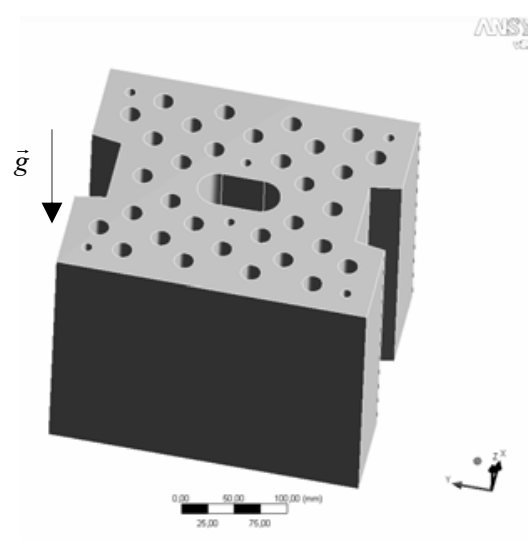

a)

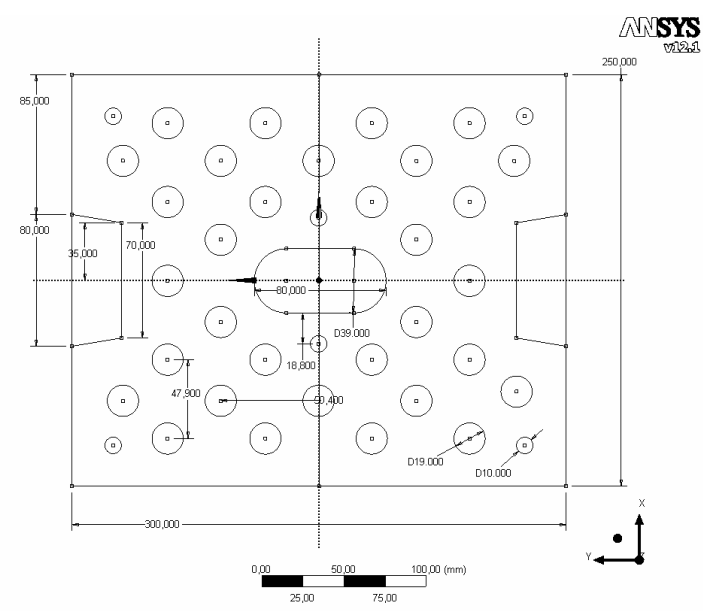

b)

Fig. 1. Geometry of the building block. 
It was assumed that there are no heat fluxes between the neighbouring blocks, therefore adiabatic boundaries were applied. Interference with the environment on the inside and outside surfaces of the block was modelled with the use of heat transfer coefficients. Since the block is symmetrical, only a half of the block was considered in the analysis, with symmetry conditions applied on the central plane. The dimensions of the block and its properties are given in Table 1.

Table 1

Dimensions and properties of the block

\begin{tabular}{|l|c|}
\hline Length/Width/Height & $300 / 250 / 249 \mathrm{~mm}$ \\
\hline Diameters of smaller cavities & $19 / 10 \mathrm{~mm}$ \\
\hline Sizes (length/width) of the largest cavity & $80 / 39 \mathrm{~mm}$ \\
\hline Heat conductivity of clay/concrete & $0.3 / 0.9 \mathrm{~W} \cdot \mathrm{m}^{-1} \cdot \mathrm{K}^{-1}$ \\
\hline Emissivity on the fluid-solid boundaries & $\underline{0.9^{*}}$ \\
\hline Heat transfer coefficient on the external/internal surface & $25 / 7.7 \mathrm{~W} \cdot \mathrm{m}^{-2} \cdot \mathrm{K}^{-1}$ \\
\hline Internal/external temperature & $293 / \underline{263} \mathrm{~K}$ \\
\hline
\end{tabular}

* underlined values are variables

In the analysis, data on the physical properties of air at $25^{\circ} \mathrm{C}$ from ANSYS CFX material library were used. Since the air is a transparent gas, the discrete radiation heat transfer model [3] was used in calculations. The air flows in cavities were assumed to be laminar. Further numerical calculations showed that the maximal Reynolds number was $R e \approx 900$, which is less than $R e_{\text {critical }} \approx 2000$ [2], so this assumption was correct. The blocks were separated from each other with a concrete gluing layer and, therefore, no-slip wall boundary conditions were used on the top and bottom surfaces of cavities.

\subsection{Mesh}

Discretization for the developed numerical model was performed using ANSYS CFX meshing tools. A fluid boundary layer was meshed with smaller elements in proximity of the faces of cavities.

The distances between nodes vary for solid domains from $1 \mathrm{~mm}$ to $10 \mathrm{~mm}$, and for fluid domains - from 0.5 to $3 \mathrm{~mm}$ (Fig. $2 a$ ). The mesh is regular in the vertical direction. A second finer mesh (Fig. $2 b$ ) was used to verify the accuracy of the results obtained. For this mesh the spacing between the elements of fluid domain was decreased to $0.3-1.5 \mathrm{~mm}$. As a result, the mesh node number was raised from $3.5 \cdot 10^{5}$ to $9.3 \cdot 10^{5}$.

The convergence criterion of $2 \cdot 10^{-4}$ maximum residual was achieved for current meshes after 50 (only conduction) to 200 (all heat transfer mechanisms) steps. The highest residuals appeared for the heat transfer inside the cavities. The time required for calculation on a $2.80 \mathrm{GHz} \mathrm{PC}$ with 8 cores varied from 30 to $90 \mathrm{~min}$, depending on the complexity of the applied heat exchange model. 


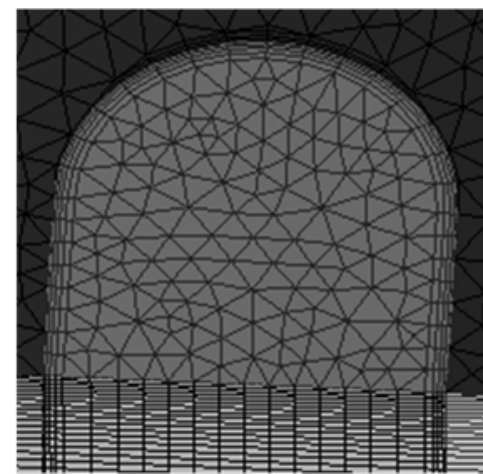

a)

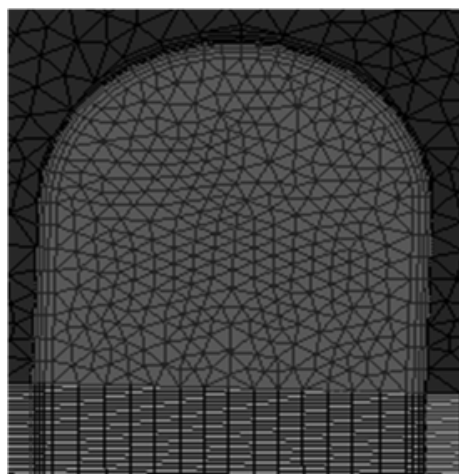

b)

Fig. 2. Discretization mesh in a cavity: a) standard. $b$ ) fine.

\subsection{Examination of the accuracy} of a mesh

Additional calculations were performed on a more accurate mesh (Fig. 2b) to examine the differences in numerical results. The issues to inspect were the correctness in representation of the radiation processes and of the convective fluxes inside the cavities. Thus, one calculation was made with an increased mesh node number inside the cavities, while the other - with an increased radiation beam number.

The last column of Table 2 shows the differences in the results calculated on coarse and accurate meshes. The difference in the effective conductivity and in other quantities is less than $0.3 \%$. Despite the difference in the maximum velocity being about $3 \%$, the convective heat transfer does not exert an appreciable influence on the heat transfer; hence, this difference can be neglected.

Calculation on different meshes

\begin{tabular}{|l|c|c|c|}
\hline \multicolumn{1}{|c|}{ Parameters } & Coarse & Accurate & Difference, $\%$ \\
\hline Max $\vec{v}, \mathrm{~cm} / \mathrm{s}$ & \multicolumn{3}{|c|}{ Convection } \\
\hline Heat flux, $\mathrm{W}$ & 6.03 & 5.86 & 2.76 \\
\hline$\Delta T, \mathrm{~K}$ & 0.953 & 0.951 & 0.19 \\
\hline$\lambda_{\text {eff }, \mathrm{W} \cdot \mathrm{m}^{-1} \cdot \mathrm{K}^{-1}}$ & 25.66 & 25.67 & 0.03 \\
\hline & 0.2486 & 0.2480 & 0.22 \\
\hline Radiation ray number & 8 & 30 & - \\
\hline Heat flux, $\mathrm{W}$ & 1.033 & 1.034 & 0.1 \\
\hline$\Delta T, \mathrm{~K}$ & 25.564 & 25.557 & 0.03 \\
\hline$\lambda_{\text {eff }}, \mathrm{W} \cdot \mathrm{m}^{-1} \cdot \mathrm{K}^{-1}$ & 0.2704 & 0.2709 & 0.15 \\
\hline
\end{tabular}




\section{RESULTS}

\subsection{Influence of different heat transfer mechanisms on the heat resistance}

Three different heat exchange mechanisms were examined: heat conduction, convection and thermal radiation. Only conduction processes are going inside the ceramic and concrete domains, while convection and radiation take place inside the air cavities. The thermal radiation is dominant in transferring the heat energy across the air domains [1].

To obtain quantitative criteria for the significance of the processes involved, four different physical models were analyzed: including only conduction mechanisms in all domains; adding convection or radiation inside the fluid domains; and, finally, including all the three mechanisms of heat transfer. The calculations were done for three air temperature differences: $10{ }^{\circ} \mathrm{C}, 20^{\circ} \mathrm{C}$, and $30^{\circ} \mathrm{C}$, for each analysis throughout the work. The results are shown in Fig. 3.

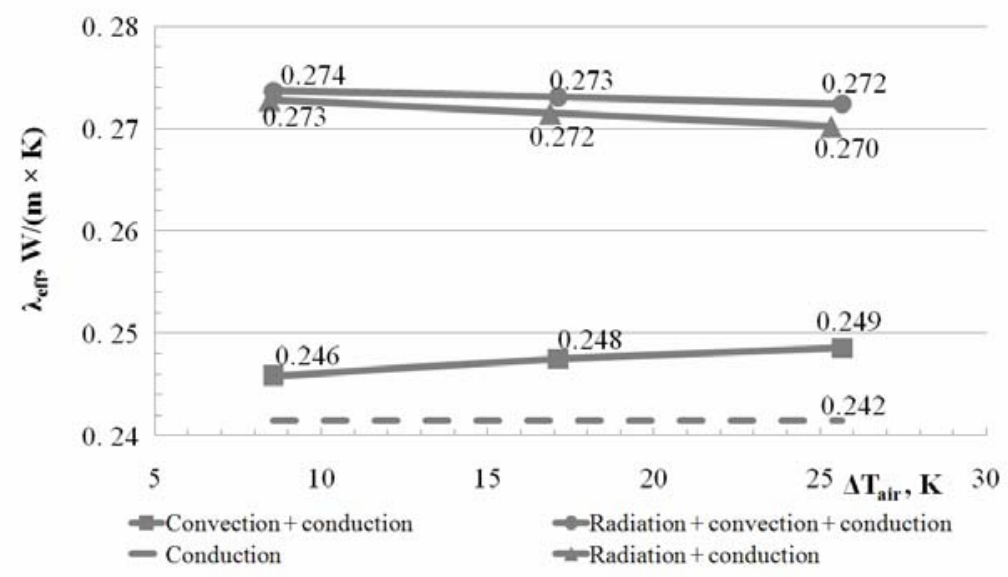

Fig. 3. The dependence of effective heat conductivity on different processes involved.

The relative differences of the effective conductivity and the clay conductivity can be calculated in order to determine the effect of cavities on the heat transfer. Observing these differences, one can see that it is theoretically possible to reduce the effective conductivity by $19 \%$ (the difference of the clay heat conductivity and the effective heat conductivity calculated without radiation and convection) if the radiation and convective mechanisms are suppressed. In the case these mechanisms are present the effective conductivity is reduced only by $9 \%$. This means that for the given geometry of a block and the clay properties the effective heat conductivity can be reduced from $9 \%$ to $19 \%$, depending on the physical properties of a cavity's filling.

As expected, radiation has the major influence on the heat transfer inside the cavities, while the convection does not lead to the changes that exceed $4 \%$ for the heat resistance. The dependence on the temperature difference with a fixed temperature of the inside air is also observed. This dependence is however weakly expressed for this type of building blocks. 


\subsection{Dependence of the heat resistivity on the properties of clay material}

Due to technological difficulties, the manufacturers cannot guarantee constant and uniform distribution of the heat conductivity for all ceramic blocks. At the same time, it is of importance for a manufacturer to know the effective heat conductivity dependence on the clay material properties in order that the production cycle is maximally efficient. Hence this dependence was to be examined, and, to achieve this goal, the calculations were made with variable $\lambda$ value in the range from 0.2 to $0.4 \mathrm{~W} \cdot \mathrm{m}^{-1} \cdot \mathrm{K}^{-1}$ (Fig. 4).

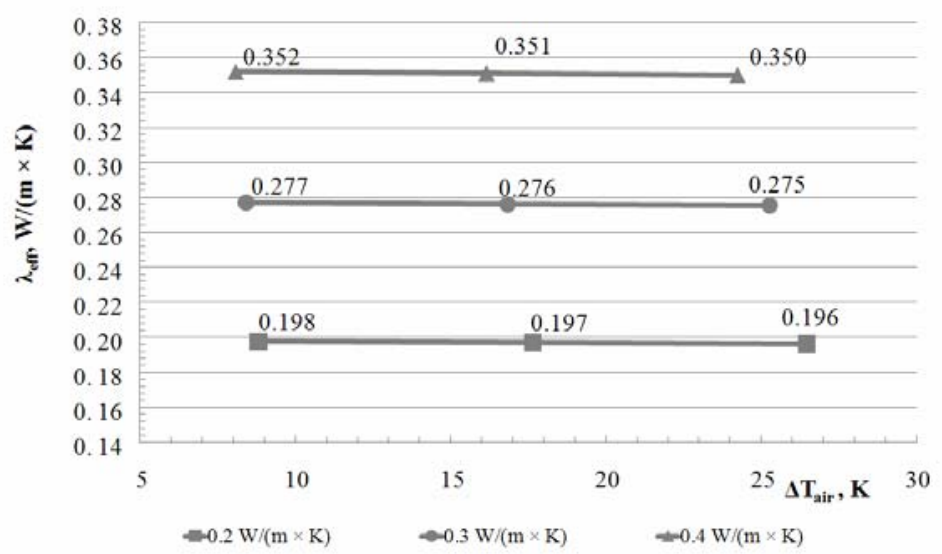

Fig. 4. The dependence of the heat resistivity on the properties of clay material.

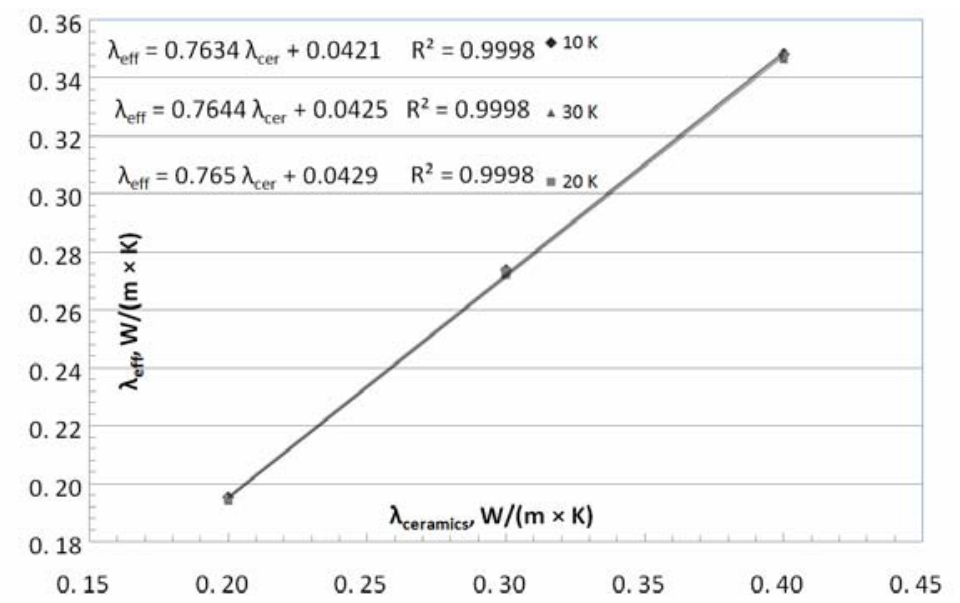

Fig. 5. The dependence of the effective heat conductivity on the properties of clay material for various temperature differences and the linear approximation.

The calculations were made involving all possible mechanisms of heat transfer. Approximation of the $\lambda_{\text {eff }}$ values obtained as a function of the clay material conductivity (Fig. 5) shows that this dependence can be treated as linear for this range, since the R-squared values for the correlation coefficients of this approximation are close to one.

The interpretation of this result can be given under the assumption that

$$
\lambda_{\text {eff }}=\lambda_{\text {ceramics }}+\Delta \lambda
$$


where $\Delta \lambda$ describes the influence of cavities on the heat exchange. Since $\lambda_{\text {eff }}$ can be expressed as a function of $\lambda_{\text {ceramics }}$, we can write:

$$
\begin{aligned}
& \lambda_{\text {eff }} \approx 0.764 \cdot \lambda_{\text {ceramics }}+0.0425=\lambda_{\text {ceramics }}+\Delta \lambda, \\
& \Delta \lambda \approx 0.0425-0.236 \cdot \lambda_{\text {ceramics }} .
\end{aligned}
$$

These equations demonstrate that the effect of cavities on the heat flux is notable only for larger conductivity values. It should be mentioned that this reasoning is correct only for the given block geometry (Fig. 1), and that these quantitative relations could vary if the geometry is changed.

\subsection{Reducing the heat resistance by changing the cavity filling}

One of the main goals of this work was to develop an easy tool for designing and testing the technical solutions, so that it could be used further for engineering of building materials with higher heat resistance. Several calculations were made as an attempt to solve the problem of minimizing the radiation heat losses in the building block under consideration to demonstrate the advantages of modelling approach.

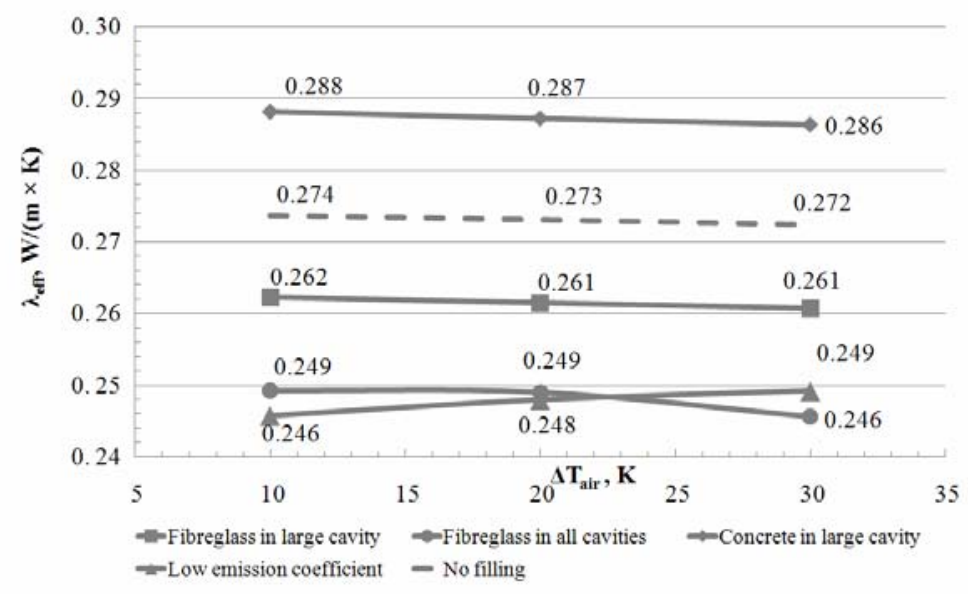

Fig. 6. The heat conductivity of a block with different cavity fillings.

One of the possible solutions was filling all the cavities or only the largest ones with mineral wool or concrete. Another option (a more complicated one in terms of technical implementation) was to spray the material with a low emission coefficient on the walls of cavities. The numerical results obtained are combined in Fig. 6. The corresponding temperature distributions on the middle cross-section at the air temperature difference of $30^{\circ} \mathrm{C}$ are shown in Fig. 7 .

The best results are obtained at using mineral wool as filling in all cavities or applying low-emission spray on the cavity walls. However, the simplest technical solution could be the use of mineral wool filling only in the largest cavity due to technical difficulties and costs of other solutions discussed above. The concrete filling is inefficient owing to its high thermal conductivity. Under certain circumstances it may however be necessary to use concrete to support the structural strength of building. 


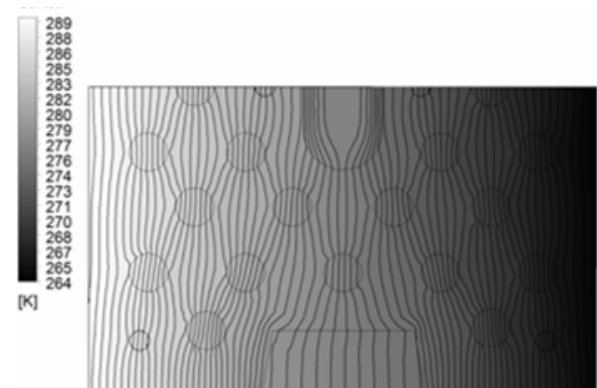

a) No filling

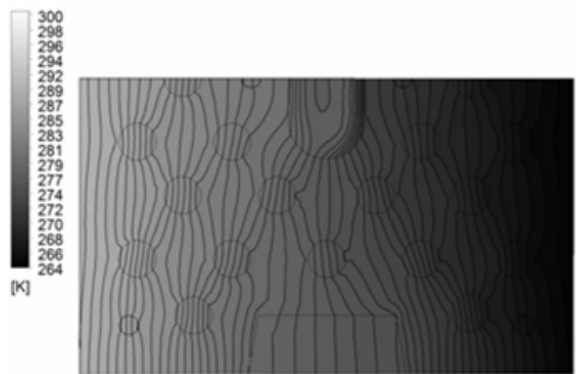

c) Low emission coefficient

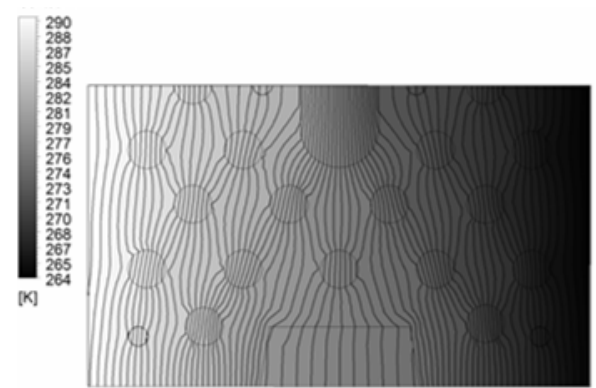

b) Mineral wool

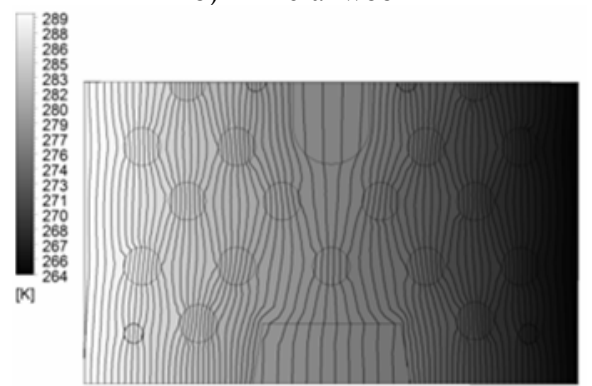

d) Concrete

Fig. 7. Temperature distribution (horizontal cross-section of the block at half its height): $a$ ) no filling, $b$ ) mineral wool in all cavities, $c$ ) low emission coefficient, $d$ ) concrete filling.

\section{COMPARISON OF EXPERIMENTAL DATA}

Additional calculation of effective heat conductivity was performed for a Keraterm 44 block with the already known experimental value of $\lambda_{\text {eff }}[4]$ to better understand how precise our calculations are as compared with the data for real buildings. For this purpose an additional model was created (Fig. 8) using the same approach as for the model described before. The effective heat conductivity value given by the manufacturer is $0.129 \mathrm{~W} \cdot \mathrm{m}^{-1} \cdot \mathrm{K}^{-1}$, which agrees with the numerical result $\lambda_{\text {calculated }}=0.146 \mathrm{~W} \cdot \mathrm{m}^{-1} \cdot \mathrm{K}^{-1}$. The difference of about $13 \%$ can be explained by the fact that the precise value of the clay material heat conductivity was unknown.

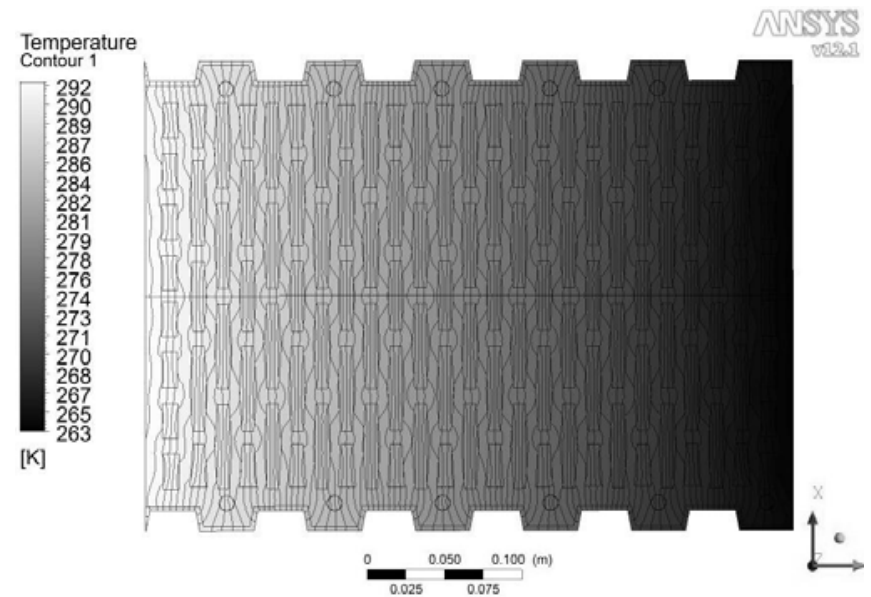

Fig. 8. Temperature distribution in Keraterm 44 block. 


\title{
5. CONCLUSIONS
}

The radiation and convection processes play important role in the heat transfer through building materials with gas cavities - the decrease in the heat resistance caused by these mechanisms reaches the level of $10 \%$. The calculations have shown that these effects can be suppressed if the cavities are filled with different insulating materials. The decrease in the effective heat conductivity is about $9 \%$ if mineral wool or spraying with a low emission coefficient is used for insulation.

The methods of numerical modelling help to point out the best choice when no other testing tools are available due to complexity of the geometry and physical properties of the heat transferring media. Based on the computer modelling these tests can be carried out in a short time and with low financial expenses.

The results are in good agreement with the effective heat conductivity values given by JSC "LODE" for the KERATERM type building blocks as well as with the works of other authors in terms of evaluating the share of different heat transfer mechanisms.

\section{REFERENCES}

1. Cepite, D. \& Jakovičs, A. (2008). Analysis of heat transfer in the structures with regularly arranged cavities. Latv. J. Phys. Tec. Sci., 45 (4), 14-24.

2. Incropera, F.P. \& De Witt, D.P. (1990). Fundamentals of Heat and Mass Transfer. New York: John Wiley \& Sons.

3. ANSYS CFX, Release 12.0 User`s Guide (2009).

4. Lodes būvniecības sistēma, 3. izd., A/S "Lode" (2010) (in Latvian)

\section{SILTUMA PĀRNESES 3D SKAITLISKĀ ANALĪZE DOBAJOS BŪVBLOKOS}

\author{
J. Grečenkovs, A. Jakovičs, S. Gendelis \\ Kopsavilkums
}

Šajā darbā ir analizēta siltuma pārnese būvniecības blokos, aprakstīta fizikāla problēma un ar ANSYS CFX programmatūras palīdzību ir izveidots viena bloka skaitliskais modelis. Darbā ir akcentēta starojuma un konvekcijas nozīme siltuma pārnesē bloka dobumos - rezultāti parāda starojuma siltuma pārneses mehānisma dominējošo tajos. Ir izpētīta siltuma pretestības atkarība no keramikas materiāla īpašībām, veikti atsevišķi mēǵinājumi būvbloka termiskas pretestības uzlabošanai uz iegūta modẹ̦a bāzes. Noslēgumā tiek diskutêti matemātiskās modelēšanas pielietošanas iespējas siltuma izolācijas materiālu ar uzdotu siltuma vadīšanas koeficientu projektēšanā.

10.02.2011 